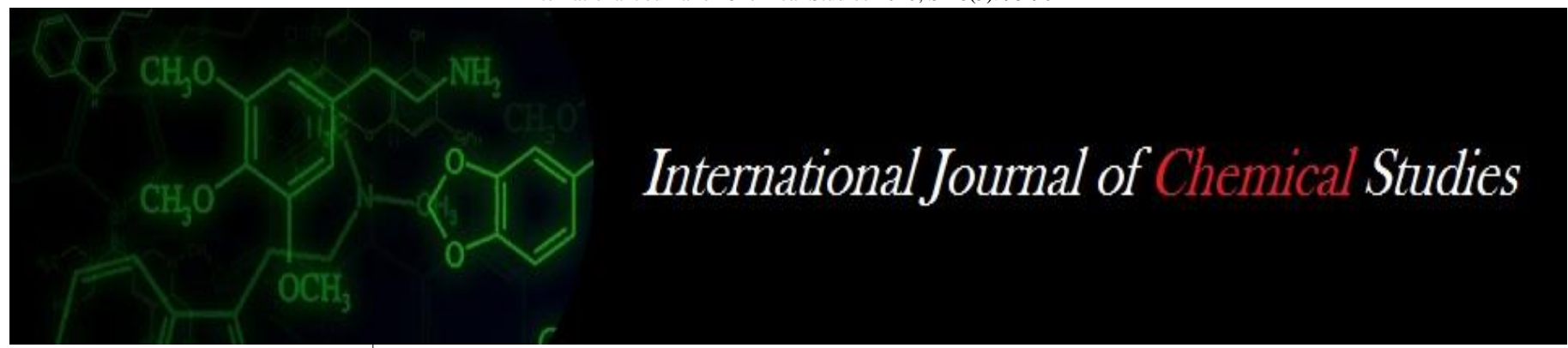

P-ISSN: 2349-8528

E-ISSN: 2321-4902

www.chemijournal.com

IJCS 2020; SP-8(5): 93-96

(C) 2020 IJCS

Received: 15-07-2020

Accepted: 20-08-2020

\section{Santoshi Choudhary}

Department of Entomology,

Indira Gandhi Krishi

Vishwavidyalaya, Raipur,

Chhattisgarh, India

Sonali Deole

Department of Entomology,

Indira Gandhi Krishi

Vishwavidyalaya, Raipur,

Chhattisgarh, India

\section{SS Shaw}

Department of Entomology, Indira Gandhi Krishi

Vishwavidyalaya, Raipur,

Chhattisgarh, India
Corresponding Author: Santoshi Choudhary

Department of Entomology,

Indira Gandhi Krishi

Vishwavidyalaya, Raipur,

Chhattisgarh, India

\section{Seasonal incidence of TIL hawk moth, Acherontia styx (Westwood) at Raipur, C.G.}

\author{
Santoshi Choudhary, Sonali Deole and SS Shaw
}

DOI: https://doi.org/10.22271/chemi.2020.v8.i5b.10435

\begin{abstract}
The field experiment were conducted at Research Cum Instructional Farm at IGKV, Raipur (C.G.) during kharif 2018. The til hawk moth appeared during $36^{\text {th }}$ SMW i.e. $1^{\text {st }}$ week of September with a mean population of 0.08 til hawk moth / plant. The peak population were $2^{\text {nd }}$ week of October $\left(41^{\text {st }} \mathrm{SMW}\right)$ with a mean population of 0.48 til hawk moth / plant. Thereafter, the population declined and reached to its minimum levels of 0.36 til hawk moth / plant during $3^{\text {rd }}$ week of October ( $42^{\text {nd }}$ SMW).The correlation between til hawk moth, Acherontia styx and weather parameters during kharif 2018 results indicated that the population showed significant positive correlation with maximum temperature $(r=0.692)$, sunshine hours $(r=0.757)$, while, significant negative correlation morning relative humidity $(r=-0.727)$ and evening relative humidity $(\mathrm{r}=-0.674)$.
\end{abstract}

Keywords: TIL hawk moth, Acherontia styx, correlation, sesame, incidence

\section{Introduction}

Sesame (Sesamum indicum L.) is one of the oldest crop and is under cultivation from ancient times (Joshi 1961; Weiss 1983) ${ }^{[4,7]}$. It gained high quality edible oil, rich source of carbohydrate, protein, calcium and phosphorous (Seegeler, 1983) ${ }^{[5]}$ and it also known as"queen of oil seeds". Sesame is grown in more than 55 countries of the world. Asia contributes more than 68 percent of the area and 67 percent production in the world. In India, sesame currently lives in an area of about 1667 thousand hectares with an annual production of 747 thousand tonnes, with an average productivity of $448 \mathrm{~kg} / \mathrm{ha}$ (Anonymous 2017) [2]. Sesame is mainly grown in kharif season under rainfed situation. One of the major in sesame production is the heavy damage caused by various insect pests. Ahuja and Bakhetia, (1995) ${ }^{[1]}$ recorded 65 insect species and one species of mite on sesame crop. Leaf webber and capsule borer, (Antigastra catalaunalis (Duponchel)), bihar hairy caterpillar, (Spilosoma oblique (Walker), whitefly (Bemisia tabaci (Genadius), and mirid bug (Crytopeltis tenuis (Reuter), green stink bug (Nezara virudula (Linnaeus), til howk moth (Acherontia styx (Westwood) is considered a regular important pests of sesame. Til hawk moth, Acherontia styx is a sporadic insect pest. However, at the larval stage it is the voracious feeder of sesame crop.

Studies on the seasonal occurrence of insect pests and their natural enemies of sesame crop and their relationship with the weather parameters provide basic information about seasonal occurrence of insect pest and their predators.

\section{Materials and Methods}

The field experiment were conducted at Research Cum Instructional Farm at IGKV, Raipur (C.G.) during kharif 2018. From the $200 \mathrm{~m}^{2}$ crop area, five sites of the samples were randomly selected and from each site five sesame plants were observed throughout the cropping period, for the presence of insect pests at seven days interval. The population of different insect pests were recorded from germination to harvest of the crop. The larval population of til hawk moth were recorded by counting the number of larvae/plant.

The data was statistically analysed by subjecting to the correlation between weather parameters and the population of insect pests which were determined using the Karl Pearson's coefficient of correlation formula: 


$$
r=\frac{\left(\sum X Y\right)-\frac{\left(\sum X\right)\left(\sum Y\right)}{N}}{\sqrt{\left(\sum X^{2}-\frac{\left(\sum X^{2}\right)}{N}\right)\left(\sum Y^{2}-\frac{\left(\sum Y^{2}\right)}{N}\right)}}
$$

\section{Where}

$\mathrm{r}=$ Simple correlation coefficient

$\mathrm{X}=$ Variable i.e. abiotic component. (Average temperature, relative humidity and total rainfall)

$\mathrm{Y}=$ Variable i.e. mean number of insect pests per plant

$\mathrm{N}=$ Number of observations.

The correlation coefficient (r) values were subjected to the test of significance using t-test

$$
t=\frac{r_{x y} \sqrt{n-2}}{\sqrt{1-r_{x y}^{2}}} \sim t n-2 d . f .
$$

\section{Where}

$\mathrm{r}=$ Correlation Coefficient

$\mathrm{n}=$ No. of observations

The calculated t-value obtained was compared with correlation coefficient table at $5 \%$ and $1 \%$ level of significance.

\section{Result and Discussion}

The til hawk moth appeared during $36^{\text {th }}$ SMW i.e. $1^{\text {st }}$ week of September with a mean population of 0.08 til hawk moth / plant. The population build up gradually and reached to its peak in the $2^{\text {nd }}$ week of October $\left(41^{\text {st }}\right.$ SMW) with a mean population of 0.48 til hawk moth / plant, when the maximum and minimum temperature, rainfall and relative humidity (mor. and eve.) were $32.4^{\circ} \mathrm{C}, 22.8^{\circ} \mathrm{C}, 0 \mathrm{~mm}, 87$ per cent and 51 per cent, respectively. Then, the population declined and reached to its minimum levels of 0.36 til hawk moth / plant during $3^{\text {rd }}$ week of October ( $\left.42^{\text {nd }} \mathrm{SMW}\right)$. The results indicated that the til hawk moth population showed significant positive correlation with maximum temperature $(\mathrm{r}=0.692)$. The regression equation being $\mathrm{y}=0.060 \mathrm{x}-1.708$ indicating that with an increase in $1{ }^{\circ} \mathrm{C}$ temperature there will be increase in population of til hawk moth by $0.060 /$ plant. The til hawk moth population also showed significant positive correlation with sunshine hours $(\mathrm{r}=0.757)$. The regression equation being $y=0.040 x-0.003$ indicating that with an increase in 1hours of sunshine there will be increase in population of til hawk moth by $0.040 /$ plant, while til hawk moth population showed significant negative correlation with morning relative humidity $(\mathrm{r}=-0.727)$. The regression equation being $\mathrm{y}=-$ $0.049 x+4.702$ indicating that with an increase in 1 per cent relative humidity there will be decrease in population of til hawk moth by $0.049 /$ plant. Til Hawk moth population showed significant negative correlation with evening relative humidity $(\mathrm{r}=-0.674)$. The regression equation being $\mathrm{y}=-0.007 \mathrm{x}+0.655$ indicating that with an increase in 1 per cent relative humidity there will be decrease in population of til hawk moth by $0.007 /$ plant. (Table 1)

Similarly, Bondre (2014) [3] studied that til hawk moth appeared during the flowering, and damage the crop till maturity stage at the crop age of 13 to 76 days. The pest attack on the flowers as well as capsule also. Thangjam and Vastrad (2018) ${ }^{[6]}$ were recorded 30 major insect pests species including, Acherontia styx, Spilarctia oblique, Nezara viridula, Dolycoris indicus, Orosius albicinctus and Bemisia tabaci.

Table 1: Seasonal incidence of Leaf webber and capsule borer infesting sesame crop and their correlation with abiotic parameters during kharif

\begin{tabular}{|c|c|c|c|c|c|c|c|c|}
\hline SMW & $\begin{array}{c}\text { Average no. of til hawk moth } \\
\text { larvae/ plant }\end{array}$ & $\begin{array}{l}\text { Max. Temp. } \\
\left({ }^{\circ} \mathrm{C}\right) \\
\end{array}$ & $\begin{array}{l}\text { Min. Temp. } \\
\left({ }^{\circ} \mathrm{C}\right)\end{array}$ & $\begin{array}{c}\text { Rain fall } \\
(\mathbf{m m})\end{array}$ & $\begin{array}{l}\text { RH (\%) } \\
\text { Mor. }\end{array}$ & $\begin{array}{l}\text { RH (\%) } \\
\text { Eve. }\end{array}$ & $\begin{array}{l}\text { Wind Velocity } \\
(\mathrm{Km} / \mathrm{h})\end{array}$ & $\begin{array}{c}\text { Sun Shine } \\
\text { (hours) }\end{array}$ \\
\hline 33 & 0 & 30.3 & 25.3 & 101.2 & 94 & 79 & 4.1 & 2.9 \\
\hline 34 & 0 & 29.0 & 24.6 & 60.4 & 93 & 79 & 5.5 & 0.6 \\
\hline 35 & 0 & 28.3 & 24.1 & 275.0 & 96 & 86 & 6.8 & 0.2 \\
\hline 36 & 0.08 & 29.2 & 23.9 & 30.2 & 93 & 57 & 0.5 & 1.1 \\
\hline 37 & 0.08 & 32.6 & 25.1 & 0.0 & 90 & 55 & 2.2 & 6.4 \\
\hline 38 & 0.28 & 31.0 & 24.1 & 32.8 & 92 & 68 & 3.5 & 3.6 \\
\hline 39 & 0.36 & 32.9 & 25.0 & 11.0 & 93 & 59 & 1.2 & 7.8 \\
\hline 40 & 0.2 & 34.0 & 23.8 & 0.0 & 91 & 44 & 0.7 & 8.0 \\
\hline 41 & 0.48 & 32.4 & 22.8 & 0.0 & 87 & 51 & 2.8 & 7.1 \\
\hline 42 & 0.36 & 33.4 & 21.3 & 0.0 & 89 & 40 & 1.0 & 8.5 \\
\hline \multicolumn{2}{|c|}{ Coefficient of correlation $(\mathrm{r})$} & $0.692 *$ & -0.583 & -0.576 & $-0.727 *$ & $-0.674 *$ & -0.508 & $0.757 *$ \\
\hline
\end{tabular}
2018

SMW: Standard Meteorological Week

*Significant at $5 \%$ level of significance

** Significant at $1 \%$ level of significance 


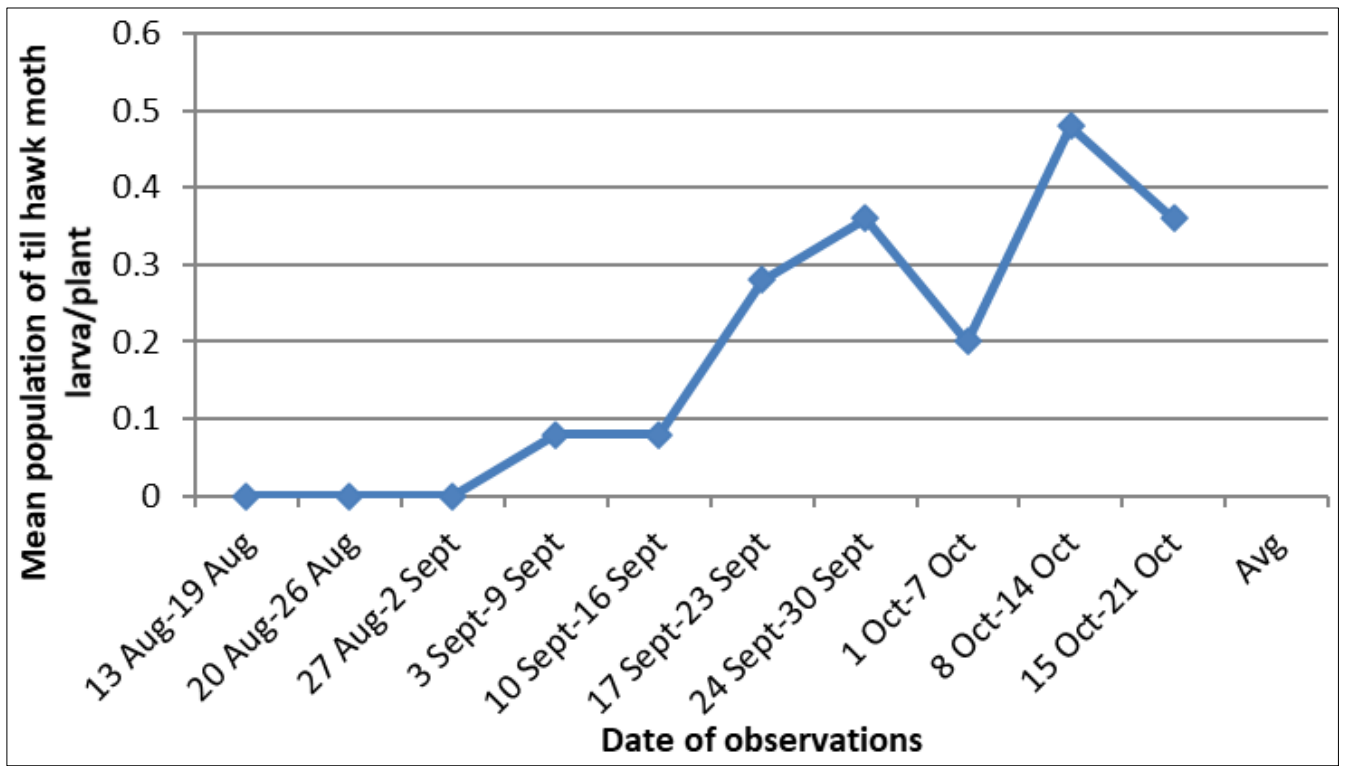

Fig 1: Mean population of til hawk moth during kharif 2018
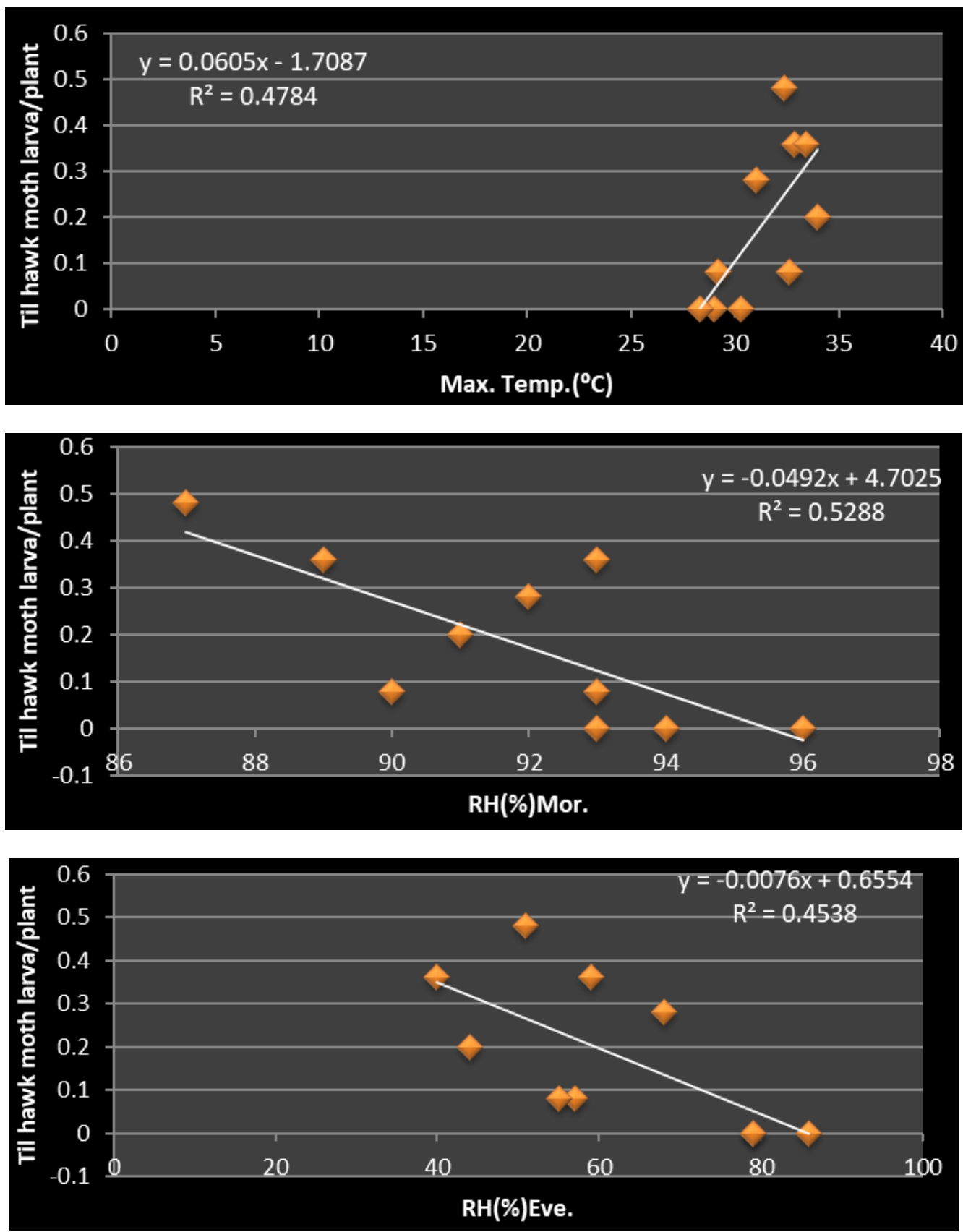


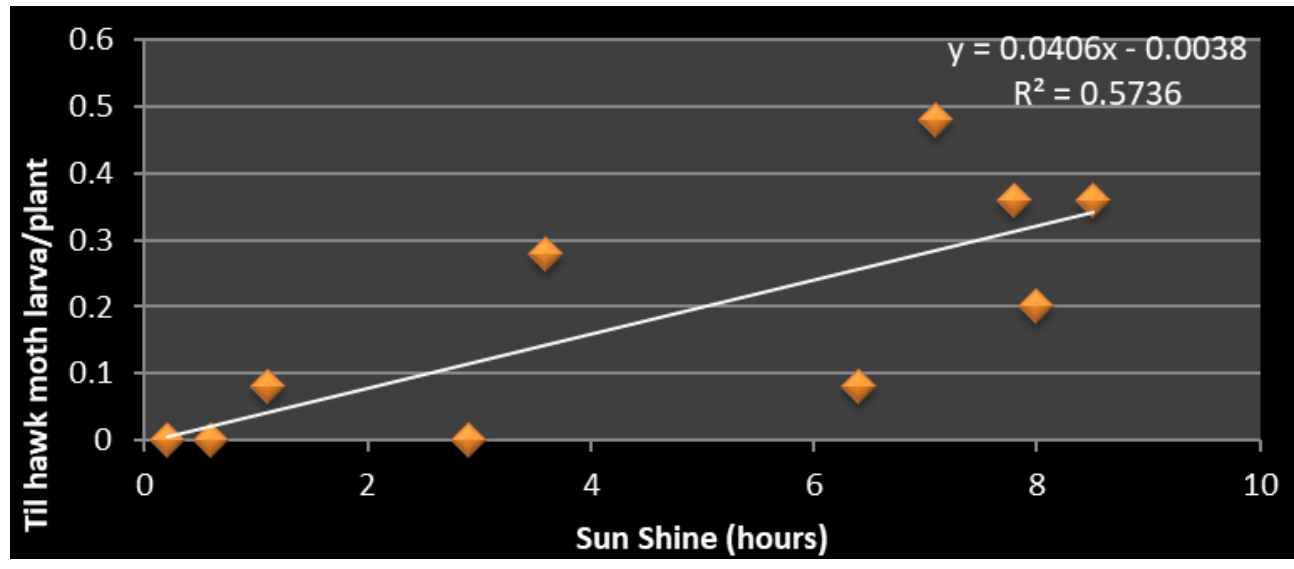

Fig 2: Regression equation between weather parameters and population of til hawk moth
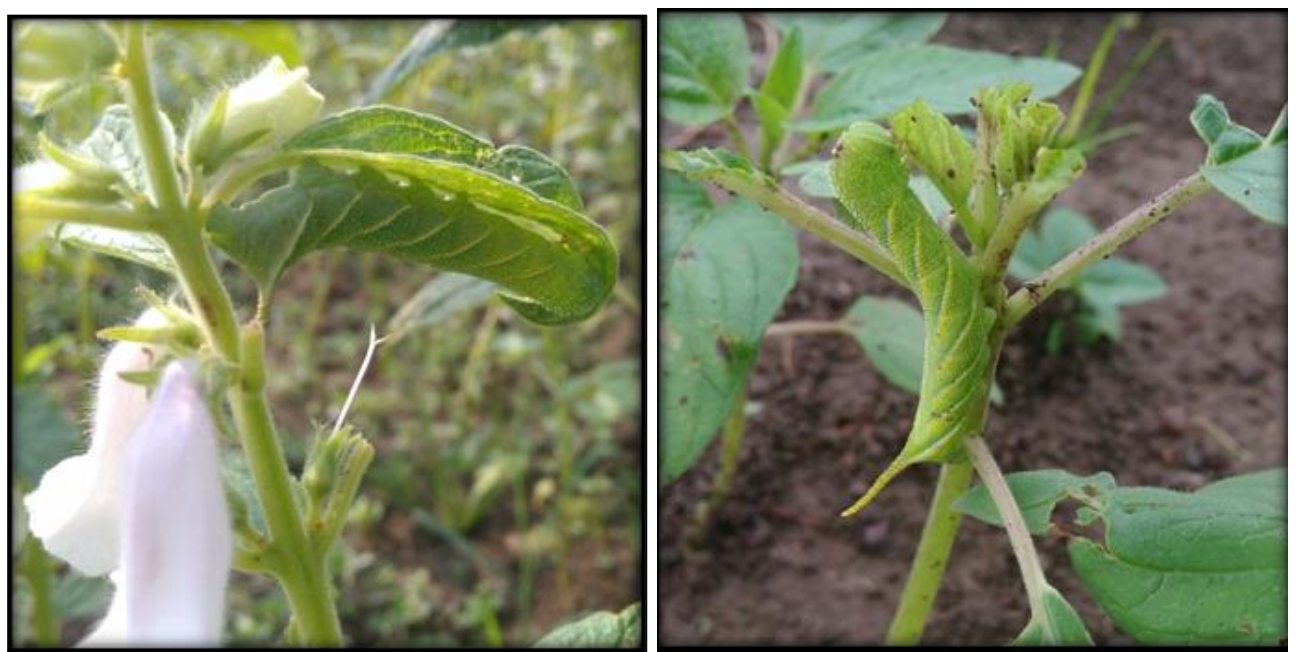

Fig 3: Damage caused by Acherontia styx at different stages of sesame crop.

\section{Conclusion}

The til hawk moth larva was appeared during $1^{\text {st }}$ week of September with a mean population of 0.08 larva / plant. The population reached to its peak in the $2^{\text {nd }}$ week of October with a mean population of 0.48 larva/ plant. Til hawk moth larval population showed significant positive correlation with maximum temperature $(\mathrm{r}=0.692)$ and sunshine hours $(\mathrm{r}=$ 0.757), while, significant negative correlation with morning relative humidity $(\mathrm{r}=-0.727)$ and evening relative humidity $(\mathrm{r}=-0.674)$.

\section{References}

1. Ahuja DB, Bakhetia DRC. Bio ecology and management of insect pests of sesame. A review journal of Insect Science. 1995; 8:1-19.

2. Anonymous. Rajasthan Agricultural Statistics at a Glance, 2015-16. Commisionerate of Agriculture, Jaipur (Rajasthan), 2017, 87.

3. Bondre CM. Studies on the population dynamics and management of major insect Pests of Sesame in Jabalpur district. M.Sc. Thesis. Jawaharlal Nehru Krishi Vishwa Vidyalaya, Jabalpur, 2014, 35-40.

4. Joshi AB. Sesame-A Monograph, Indian Central Oilseeds Committee Hyderabad India, 1961, 267.

5. Seegeler CJP. Oil plants in Ethiopia, their taxonomy and agricultural significance. Centre for Agricultural publishing and documentation, Wageningen, 1983, 120121.

6. Thangjam R, Vastrad AS. Studies on pest complex of sesame and their natural enemies in North Karnataka,
India. Journal of Entomology and Zoology Studies. 2018; 6(6):57-60.

7. Weiss EA. Oilseed Crops. Longman, Essex, U.K, 1983, 282-340. 